\title{
СФЕРИ І ФУНКЦІЇ ПРОФЕСІЙНОЇ ДІЯЛЬНОСТІ ЛІКАРІВ В АВСТРІЇ
}

І. М. Мельничук

\author{
ДВНЗ “Тернопільський державний медичний університет імені І. Я. Горбачевського МОЗ Украӥни”
}

\section{FIELDS AND FUNCTIONS OF THE PROFESSIONAL ACTIVITY OF DOCTORS IN AUSTRIA}

\author{
I. M. Melnychuk \\ SHEI “Ternopil State Medical University by I. Ya. Horbachevsky of MPH of Ukraine”
}

\begin{abstract}
Розглянуто сфери та об’єкти професійної діяльності австрійських лікарів. Охарактеризовано функції діяльності лікарів в Австрії, що виокремлюються залежно від характеру їх праці. Виділено етапи становлення професійної групи лікарів Австрії. Висвітлено основні критерії, що характеризують професійну групу лікарів. Проаналізовано характеристики професійної групи лікарів і чинники, що впливають на їі розвиток і зміни у ній. Конкретизовані види діяльності і професійні завдання, у яких мають бути компетентними та обізнаними випускники австрійських вищих медичних навчальних закладів.
\end{abstract}

Fields and objects of the professional activity of Austrian doctors are considered. Functions of the activity of doctors in Austria that are marked out depending on the nature of their work are characterized. The periods of development of the professional group of doctors in Austria are singled out. The basic criteria that characterize the professional group of doctors are covered. The characteristics of the professional group of doctors and factors influencing its development and changes in it are analyzed. Activities and professional objectives, which the graduates of Austrian medical universities must be competent and knowledgeable in, are singled out.

Вступ. Медичні працівники - це професійна група людей, пов'язаних із складною розумовою працею, що об'єднує осіб із середньою та вищою медичною освітою, зайнятих у сфері охорони здоров'я. Медицина це система наукових знань і практичної діяльності фахівців зметою зміцнення і збереження здоров'я, продовження життя людей, попередження та лікування хвороб. Лікарі як професійна група - невід'ємна частина будь-якого суспільства. Професійну групу лікарів характеризують за певними критеріями:

- за сферою діяльності, спрямованої на збереження та поліпшення здоров' я громадян, надання їм висококваліфікованої медичної допомоги, що потребує фахової підготовки медичних кадрів, управління персоналом лікувально-профілактичних установ, органами системи охорони здоров'я, санітарно-освітньої та наукової роботи;

- за способом організації професійної діяльності, оскільки діяльність фахівців медицини здійснюється у медичних установах, вищих медичних навчальних закладах, органах управління охорони здоров'я [2].

Вивчення функцій професійної медичної діяльності стає все більш актуальним у соціальному аспекті, що зумовлено великим практичним інтересом до ефективної роботи лікарів. Соціально-економічні зміни в сучасному суспільстві зумовили необхідність перетворень у сфері охорони здоров'я, яка набуває нових функцій під впливом нових економічних відносин, зміни законодавства тощо.

Певні аспекти професійної діяльності лікарів розглядали у своїх працях як вітчизняні, так і зарубіжні науковці, серед яких А. Агаркова, 3. Гаппель, Т. Еллігер, Р. Кайзер, 3. Кьолер, Р. Райман, Р. Траппл, Б. Шобер, К. Шпіль та ін.

Метою статті $є$ аналіз сфер і функцій професійної діяльності австрійських лікарів.

Основна частина. Провідним чинником розвитку професійної групи лікарів Австрії виступає їх професійна діяльність, яка знаходить конкретне відображення у змінах, що відбуваються в суспільстві. У цілому стан здоров'я населення та якість надання медичної допомоги досить точно відображають економічний стан держави. Узагальнюючи вищесказане, конкретизуємо кілька етапів у процесі становлення професійної групи австрійських лікарів:

- виділення основних засад медичних знань, викликаних необхідними потребами людей;

- поява осіб, що беруть на себе функції лікування, вироблення певних технологій праці, перетворення їх у необхідні послуги (товар); 
- формування шляхів відтворення окресленої професійної групи, а також її професійної ідеології;

- поява системи спеціальної освіти, тобто завершення процесу інституалізації професії, що сприяє остаточному формуванню професійної групи;

- створення громадських організацій, що забезпечують життєдіяльність професійної групи і виконують функції контролю за їі діяльністю;

- створення професійного об'єднання медиків, що виражає інтереси суспільства в цілому [7].

Отже, в соціальній структурі австрійського суспільства група медичних працівників займає важливе місце. Вона формується як самостійна протягом тривалого історичного періоду. Її ядром є група лікарів. Загалом медичних працівників i, зокрема, лікарів традиційно ідентифікують за певними групоутворюючими ознаками (наявністю спеціальної освіти, способом організації професійної діяльності, наявністю професійної мови, внутрішньої організації) [9], що сприяє їхній професійній ідентифікації.

Оскільки праця лікарів має ознаки інтелектуальнопрофесійної діяльності, отже, це кваліфікована розумова праця. Мінімізація фізичних зусиль, які затрачаються під час розумової праці, досягається в австрійській медицині за допомогою використання сучасної медичної техніки. У результаті розвитку і вдосконалення технічних засобів професійної діяльності фахівців медицини, інформаційних технологій, нових методів діагностики та лікування хвороб, зміст праці лікарів Австрії трансформується. Адже розвиток інформаційних технологій і використання новітньої сучасної техніки у медицині - це один із важливих показників ефективності надання медичних послуг. Зазначені засоби праці лікаря допомагають знизити рівень захворюваності та смертності населення за рахунок поліпшення діагностики, лікування, профілактики та управління мережею охорони здоров'я. Використання телекомунікацій у медичних закладах Австрії допомагає поліпшити зв’ язки між периферійними лікувальними установами та провідними клінічними центрами [11].

Розвиток суспільства висуває все більше вимог до медичної професії. Одними з головних є підвищення якості та культури надання спеціалізованої, кваліфікованої медичної допомоги, розробка та впровадження у практику нових науково обгрунтованих технологій в діагностиці та лікуванні захворювань. Усі ці вимоги обумовлені появою нових перспективних методів лікування, вдосконаленням медичних послуг, комп'ютерних технологій, успіхами біологічної науки, генної інженерії, трансплантології, появою нових лікарських засобів, способів і методів контролю за станом органів людини та їх функцій, вдосконаленням міні-інвазивної хірургії, ендоваскулярної хірургії, анестезіологіï, реаніматології.

На зміну стандартних методів досліджень прийшли сучасні лабораторні, комп'ютерні томографічні та ангіографічні методи. Під впливом науково-технічної революції в австрійській медицині все ширше застосовується автоматизація, комп'ютерна техніка та інші досягнення сучасної науки. Такі зміни вимагають залучення у сферу охорони здоров'я працівників інженерних та технічних спеціальностей, що істотно впливає на внутрішню структуру медичної професії. У сучасному етапі розвитку медицини лікар повинен володіти різнобічними знаннями 3 фаху, методами наукових досліджень, вмінням творчо мислити, швидко орієнтуватися в складних професійних ситуаціях, відрізнятися рішучістю дій [10].

Як і в будь-якій сфері інтелектуальної діяльності, в медицині існує свій реєстр спеціальностей, який передбачає наявність певних кваліфікаційних вимог i виконання відповідних функціональних обов'язків. Сфери професійної діяльності лікарів Австрії визначаються набутою ними спеціальністю і включають:

- практичну охорону здоров’ я;

- наукову діяльність;

- освітню діяльність;

- управління закладами охорони здоров’я.

Об'єктами професійної діяльності австрійських лікарів є: здоров'я населення Австріі, установи та організації охорони здоров' я різного відомчого підпорядкування та форм власності, науково-дослідні установи, підприємства та організації, пов' язані з наданням медичної допомоги та наданням медичних послуг населенню, військовослужбовцям, а також установи, що забезпечують отримання медичної освіти.

Після закінчення інтернатури випускники медичних університетів Австрії мають бути компетентним у таких видах діяльності, як:

- профілактична допомога;

- медична допомога;

- науково-дослідна діяльність;

- викладацька діяльність;

- організаційно-управлінська діяльність.

Крім того, випускники мають бути обізнаними у вирішенні таких професійних завдань, як:

- профілактика захворювань і поліпшення здоров'я населення;

- діагностика захворювань, лікування і реабілітація хворих; 
-інформаційно-аналітична діяльність 3 метою оцінки і прогнозування стану здоров’я населення;

- планування, організація та управління наданням медичної допомоги населенню в установах та організаціях охорони здоров’я;

- планування та проведення наукових досліджень відповідно до отриманої спеціальності ( в установах та організаціях охорони здоров'я, соціального захисту, у вищих та середніх навчальних закладах, у науково-дослідних організаціях за профілем “Охорона здоров’я”, у медичних установах, організаціях та їх підрозділах), незалежно від відомчої приналежності.

Після закінчення терміну навчання випускники австрійських медичних університетів набувають:

- сформовану особисту потребу в подальшій безперервній освіті, підвищенні кваліфікації;

- професійну мобільність як можливість подальшого здобуття будь-якої клінічної і наукової медичної спеціальності;

- можливість перепідготовки відповідно до змін ринку праці в охороні здоров'я, особистих потреб [3].

У зв'язку з розвитком австрійського суспільства, впливом конкретних історичних умов відбувається і розвиток медицини як галузі знань. Спочатку медицина була народною. У результаті поділу праці з'явилися люди, які претендували на виконання функцій лікування в суспільстві. Накопичені знання і вміння передавалися з покоління в покоління. Встановлювалися зразки поведінки членів цієї професійної групи. Медицина переживала ремісничий період розвитку (співіснування понять “лікар”, “майстер”). Середньовічна медицина носила відбиток церкви і схоластики, мала безліч догматичних підходів до лікування хвороб. Епоха Відродження в Австрії, що базувалася на відкриттях античності, дала поштовх розвитку професійної медичної діяльності. 3' явилися перші університети 3 відкриттям у них медичних факультетів. Подальше накопичення медичних знань пов'язано з численними природно-науковими відкриттями, що, в свою чергу, сприяло спеціалізації медицини. Цей процес зробив свій вплив на професійні функції австрійських лікарів у напрямку їх ускладнення [4].

Важливим об'єктивним фактором, що впливає на виконання професійних функцій лікарів, є територія. Аналіз медичної діяльності лікарів в Австрії дозволяє зробити висновок про те, що на певній території, в силу природно-кліматичних умов, демографічних, статевовікових особливостей, розвиток матеріального виробництва має свої риси, що здійснює істотний вплив на надання медичної допомоги населенню. Для всіх територій єдиним є характер медичної діяльності, але економічна основа існування у всіх різна. Незважаючи на те, що діяльність лікарів спрямована на збереження і зміцнення здоров’я людей, характер діяльності, робоче місце, знаряддя праці у них різні. Економічні характеристики соціально-професійної групи лікарів Австрії відрізняються. Так, система оплати праці та матеріального стимулювання для кожного лікаря визначається кваліфікацією, стажем роботи, специфікою установи, умовами праці [4].

У зв'язку зі спеціалізацією і різким зростанням інструментальних і лабораторних методів обстеження в Австрії інтенсифікується діяльність кожного окремого спеціаліста, а кожного хворого ставлять перед необхідністю звертатися в процесі обстеження і лікування до значної кількості фахівців. Зростає число контактів і зменшується їх тривалість. Втрачає силу принцип “лікувати не хворобу, а хворого”, відбувається “деперсоніфікація” хворого як споживача медичної допомоги. Тенденція змін у професійній діяльності австрійських лікарів, пов'язана з розвитком науково-технічного прогресу, новими формами організації медичної допомоги [5].

Складність структури медичної діяльності в Австрії визначається різноманіттям іiі функцій. Залежно від характеру праці лікарів виділяють такі функції: лікувально-профілактичну, відтворювальну, управлінську, соціально-гуманістичну, виховно-педагогічну, соціально-престижну, культурно-творчу.

Засадничою для лікарів є лікувально-профілактична функція, в основі якої профілактика - головний напрям. На сьогодні ця функція набула особливого значення і стала найбільш адекватним способом реалізації сутності медичної професії. Вона у своєму предметному змісті включає: здійснення прийому хворих, відвідування хворих удома, профілактичну роботу (вакцинація, заходи з попередження інфекційних захворювань), лікування хворих у стаціонарі, надання екстреної допомоги, направлення за показаннями на госпіталізацію, направлення на консультацію до фахівців, проведення експертизи тимчасової непрацездатності, проведення медичних оглядів, обстеження хворих за допомогою сучасного медичного обладнання, ведення облікової та звітної документації тощо. Науковий напрямок цієї функції визначено в силу того, що реалізація медичної діяльності неможлива без наукового фундаменту.

Медична наука покликана вивчати морфо-фізіологічні та психоемоційні умови людського існування в його зв' язку із соціальними і природно-кліматичними умовами життя, прогнозувати динаміку захворюваності тощо. Відновно-оздоровчий напрям має та- 
кож профілактичний характер. Його сутність полягає у відновленні здоров'я пацієнта після перенесеного захворювання, підтриманні необхідного рівня якості здоров' я. На сучасному етапі в Австрії більш досконалим став розвиток профілактичної медицини. Структурними підрозділами системи охорони здоров'я (центри медичної профілактики, медичні інформаційно-аналітичні центри, відділення, кабінети профілактики) проводиться:

- добровільна (за ініціативою обстежуваного), планова індивідуальна і масова скринінг-діагностика із визначення рівня і резерву здоров'я населення, оцінка функціональних резервів організму;

- розробка засобів оперативного медичного контролю за особами, що беруть участь в оздоровчих заходах;

- розробка технологій омолоджування і активного довголіття;

- розробка нових методів експрес-діагностики;

- створення єдиної системи диспансеризації населення.

Відтворювальна функція. У своєму конкретно-предметному змісті вона передбачає відтворення робочої сили, відіграючи в цьому істотну, хоча й опосередковану роль, і спрямована на економне витрачання живої праці. Особливу соціальну значимість ця функція набуває в сучасних умовах, у зв'язку з тим, що ринок медичних послуг має особливості на різних рівнях надання медичної допомоги. У даному випадку з позицій регульованого ринку одне з основних завдань для організаторів охорони здоров'я - наповнення даного сегмента ринку мінімально необхідним набором медичних послуг. У системі охорони здоров'я повинні домінувати елементи прогнозування і планування, що базуються не тільки на ресурсних показниках, але й на потребах населення в медичній допомозі.

Управлінська функція включає в себе управління процесом формування, підготовки, використання та розподілу кадрів медичної професії, управління системою організації охорони здоров’я, управління підвищенням ефективності медичної праці тощо. Цю функцію можна розподілити на:

1) участь в управлінні відтворенням робочої сили;

2) експертно-розподільну, оскільки лікар бере участь в ролі експерта у розподілі суспільних фондів споживання;

3) регулюючу, оскільки праця по рівноправній охороні здоров'я виступає фактором вирівнювання соціальної нерівності.

Сочуіально-гуманістична функція включає в себе напрямок з формування здорового способу життя.
Вона охоплює різні сторони людської життєдіяльності: спосіб життя, сім’ю, шлюб, демографію, урбанізацію, екологію тощо. На сьогодні формування здорового способу життя серед населення особливо актуальне і необхідне, оскільки потребують покращення показники якості здоров’я, має місце ведення нездорового способу життя, зневажливе ставлення до свого здоров'я. Зважаючи на погіршення екологічної ситуації, соціально-гуманістична функція активізується у проведенні вторинної профілактичної роботи, коли вже лікарі мають справу з різними недугами, пов’язаними з екологічним середовищем. Реалізація даної функції відбувається шляхом безпосереднього особистого спілкування, виступами в засобах масової інформації, у діяльності різних медичних організацій. Сюди відноситься і система орієнтованих шкіл при конкретних захворюваннях, які створюються для профілактики ускладнень при таких захворюваннях, як гіпертонічна хвороба, цукровий діабет, бронхіальна астма.

Педагогічно-виховна функція. Значення іï в сучасних умовах зросло в силу появи нових вимог до суб'єкта медичної діяльності, розвитку медичної науки як такої, потреби у формуванні професійної культури фахівця і медичної культури населення. Педагогічно-виховна функція не обмежується лише стінами навчального закладу. Лікарі є тим середовищем, де триває процес формування, підготовки та виховання людини, що вступила у сферу професійної медичної діяльності. Сюди відноситься і постійна самоосвіта, участь у громадському житті лікувального закладу, розробці та впровадженню інноваційних технологій, санітарно-освітній роботі серед населення, видання публікацій, участь у медичних конференціях, конкурсах професійної майстерності, наставництво і робота зі студентами медичних навчальних закладів.

Соціально-престижна функиія спрямована на формування професійного авторитету, підвищення престижності медичної професії. Лікар у процесі спілкування з пацієнтами несвідомо чи усвідомлено, своєю розмовою, поведінкою, професійними діями, формує у людей уявлення не тільки про самого себе як фахівця чи особистості, він перш за все створює можливість оцінити свою професію іншими людьми, формує їі професійну і соціальну значимість. Ця функція сприяє професійній орієнтації і вибору майбутньої професії серед молодіжної аудиторії.

Культурно-мистецька функція різноманітна у своїх проявах. Вона включає трудову творчість, науково-технічну, соціально-політичну, духовну. Трудова творчість є формою різних трудових починань, в 
організації самоврядування, у розробці творчих планів, у діяльності із впровадження новітніх досягнень у медичній науці тощо. Науково-технічна творчість полягає у раціоналізації та винахідництві, які є результатом удосконалення професіоналізму медичних працівників. Соціально-політична творчість проявляється в активізації політичної діяльності, політичної зацікавленості. Духовний напрямок реалізується у формі художньої самодіяльності, образотворчого мистецтва, літературній творчості тощо. Слід відзначити той факт, що в професійних функціях лікарів багато часу займають адміністративні функції (господарські, оформлення медичної документації, управлінські). Лікарі відзначають, що цей факт заважає їм якісно і в строк виконувати свої посадові обов'язки [11].

Зокрема, у професійних функціях хірургів змінилися підходи до хірургічного втручання, оперативного лікування у зв' язку з новим медичним обладнанням, з упровадженням новітніх наукових розробок. У функціях акушерів-гінекологів 3'явилися зміни у спостереженні категорії пацієнтів - впроваджена система безперервного спостереження, УЗД-скринінги, виявлення ранньої патології внутрішньоутробного розвитку плода за допомогою новітньої техніки.

Проведення моніторингу здоров' я населення в Австрії теж позначилося на професійній діяльності лікарів. Раннє виявлення захворювань привело до збільшення кількості звертань до лікарів за наданням медичної допомоги. У лікарів-епідеміологів змінилися схеми лікування інфекційних захворювань у бік використання лікарських препаратів нового покоління. Вибір лікарем оптимальних методів діагностики та лікування іззростаючої кількості терапевтичних засобів є складним інформаційним завданням. Розвиток інформаційних технологій в австрійській медициніє необхідністю, обумовленою економічними тенденціями. Провідна роль у медичних інформаційних технологіях відводиться запобіганням медичним помилкам. Телемедицина дозволяє використовувати дуже складні форми передачі інформації. Не можна не відзначити факт передачі медичної інформації туди, де відстань є критичним фактором. На базі телемедичних центрів проводяться консультації хворих і теленавчання лікарів [6].

Проведений аналіз показує, що здебільшого оцінка професійних функцій лікарів визначається підняттям престижу праці медичних працівників, новими організаційними рішеннями з боку держави, значними матеріальними внесками у підтримку і розвиток галузі охорони здоров’я.

Вибір пріоритетів в охороні здоров'я намітився в Австрії в останні десять років. Основним напрямом удосконалення системи управління в охороні здоров'я стає забезпечення їі цілісності за рахунок єдиних систем планування, нормування, стандартизації, ліцензування, сертифікації, єдиної технологічної, технічної і кадрової політики, а також чіткого поділу компетенції між федеральним, земельним, муніципальним рівнями. Перспективи розвитку охорони здоров'я Австрії значною мірою залежать від стану професійного рівня і якості підготовки медичних кадрів, як головного ресурсу охорони здоров'я [2].

Одним із завдань реформи охорони здоров'я Австрії і соціального благополуччя є підвищення громадської задоволеності медичним обслуговуванням. Все це вимагає перетворення моделі професійної діяльності медичних працівників і системи охорони здоров’я. Лікарі в сучасному світі зберігають своє положення і зміст діяльності, роль їх професії анітрохи не зменшується, а швидше зростає. Поява нових хвороб, боротьба медиків з уже наявними, зростаюча увага великої кількості членів суспільства до свого здоров'я сприяють збереженню і зміцненню становища лікаря у суспільстві, в першу чергу, в силу специфіки їх діяльності. Обставини зобов' язують лікарів вирішувати складні питання як професійні, так і етичні, соціальні, психологічні, правові тощо. Причому необхідно враховувати національну специфіку та традиції щодо вирішення багатьох питань у здійсненні професійної лікарської діяльності. Лікар повинен швидко приймати управлінські рішення в межах своєї компетенції в таких питаннях, як застосування апаратів для підтримки життя в критичних ситуаціях, трансплантація органів і проблема донорства. Необдумане застосування медичних досягнень може призвести до зміни рівноваги ціннісних орієнтирів у суспільстві. Отже, до чинників, що зумовлюють необхідність формування нової парадигми організаційно-методичного забезпечення медичної діяльності, доцільно віднести:

-інтенсивний розвиток нових медичних технологій;

- необхідність безперервної медичної освіти, як фактора забезпечення якості медичної допомоги;

- більш оперативне інформаційне забезпечення служби;

- ліцензування медичної і фармацевтичної діяльності;

-інноваційні технології в галузі діагностики й оперативного лікування;

- рекомендації, вироблені з урахуванням кращого досвіду в медичній галузі;

- розвиток відновлювальної медицини шляхом застосування переважно немедикаментозних методів; 
- диференційована підготовка медичних кадрів залежно від потреби населення, зростання медичних послуг [8].

Розглядаючи медичну професію в аксіологічному плані, необхідно зазначити, що ії структурування відбувається навколо системи моральних цінностей. Медична етика має ряд істотних відмінностей, головними 3 яких є домінанта деонтологічної проблематики і певне посилення неформальних санкцій, у порівнянні з іншими етичними системами [9].

Зростання уваги до етичної культури лікаря зумовлено як об' єктивними труднощами, з якими стикаються лікарі під час діяльності, так і розвитком теоретичної та практичної медицини. Сьогодні розвиток трансплантології, неонатології, ендоскопії, фармакології тощо забезпечує можливість подолання захворювань та травм, які вважалися смертельними ще кілька десятиліть тому [1]. Аналіз наукових досліджень доводить, що питання нормативної професійної етики і деонтології розглядали у своїх роботах Р. Апресян, Ю. Шрейдер, Р. Шпеман та ін. Медична етика і деонтологія, що вивчають принципиповедінки медичного персоналу, спрямовані на максимальне підвищення ефективності лікування, проблеми виключення несприятливих чинників у професійній поведінці лікарів, систему взаємовідносин між медпрацівниками в колективі, а також у роботі з пацієнтами, способи усунення шкідливих наслідків неповноцінної медичної допомоги.

Певні вимоги до професійної поведінки лікарів складають предмет вивчення медичної етики. Роз'єднувати зміст терміну “деонтологія” з його тлумаченням в етичній науці недоцільно. Деонтологія є вченням про моральний обов’ язок і як така є частиною етики. Деонтологія в медицині-це конкретизація медичної етики у відповідності з різними спеціальностями, різними сферами медичної діяльності, різними ланками медичної праці; це колективний моральний, духовно-практичний досвід медицини, школа професіоналізму в медицині, мистецтва вибору найоптимальніших засобів для затвердження медичного гуманізму; це застосування на практиці принципів і норм медичної етики з метою максимального підвищення суми суспільної корисності і максимального усунення шкідливих наслідків неповноцінної медичної допомоги [2].

\section{Література}

1 Агаркова А. О. Деякі аспекти формування професійно-етичної культури майбутнього лікаря / А. О. Агаркова // Вісник ЛНУ імені Тараса Шевченка. - 2010. - № 7 (194). - C. 10-14.

2.Aerztliches Berufsrecht [Електронний ресурс]. - Режим
Відомо, що науково-технічний прогрес супроводжується впровадженням у практику охорони здоров'я модернізованого медичного обладнання, які змушують по-новому розглядати традиційні норми медичної етики. Наприклад, сучасні можливості реанімації іноді вступають у протиріччя з моральними поняттями, що ставить лікаря в скрутне становище під час виконання ним лікарського обов’ язку. Так, за допомогою сучасного обладнання і відкриттів у фармацевтичній галузі можна зберігати людині життя протягом тривалого часу, знаючи, що значні зміни в корі головного мозку спричинять за собою певну соціальну неповноцінність особистості. У даний час є багато випадків, коли люди, не приходячи до тями, живуть в реанімаційних відділеннях тижнями і місяцями. Лікарі впевнені у безперспективності лікування такого хворого, але не мають морально-етичного права відключити апарати штучного дихання і кровообігу, оскільки в протилежному випадку їх дії можуть розглядатися як евтаназія.

Серйозні морально-етичні проблеми виникають у ряді випадків при трансплантації органів і тканин живих осіб і трупів, у роботі медико-генетичних консультацій (штучне запліднення, вибір статі тощо). Зміни відбуваються у морально-етичній свідомості лікарів. Сьогодні медична мораль не здатна виступати в якості регулятора суспільних відносин, із зростанням технічного прогресу в медицині моральні норми трансформуються у правові. Сприяючи гуманізації медицини, етика впливає на формування професійної самосвідомості медиків, формуючи й оновлюючи моральні регулятори когорти медичних працівників, структурує дану професійну групу навколо системи моральних цінностей [11].

Висновки. Отож, грунтовний аналіз наведених матеріалів засвідчує, що провідним чинником розвитку професійної групи лікарів Австрії виступає їх професійна діяльність. Лікарі покликані бути кваліфікованими фахівцями, що не лише розуміють свої вузькопрофесійні завдання, а й обізнаними у питаннях медичної етики, психології, юриспруденції, інформаційних технологій, нових методів діагностики та лікування хвороб, адаптованими до змін, що відбуваються у суспільстві.

доступу: < http://www.fa-gesundheitsberufe.at/component/ content/article/83-lexikon/160-aerztliches-berufsrecht>-3aгол. $з$ екрана. - Мова нім.

3. Die Zielgruppe des FA Gesundheitsberufe [Електронний peсурс]. - Режим доступу : < http://www.fa- 
gesundheitsberufe.at/der-fachausschuss-menu-fagesundheitsberufe-130/zielgruppe-menu-fagesundheitsberufe-132> - Загол. з екрана. - Мова нім.

4. Elliger T. Die Medizinerausbildung in Osterreich. Analyse eines Studiengangs in seinem historischen und sozialen Kontext / Tilman Elliger. - Munchen, 1986. - $250 \mathrm{~s}$.

5. Guidance on CPD [Електронний ресурс]. - Режим доступу : http://www.gmc-uk.org/education/continuing professional_development/cpd_guidance.asp -Загол. 3 екрана. - Мова англ.

6. Happel S. Arzthelferinnen sollen Krankenhausarzte von Verwaltungstatigkeiten entlasten / S. Happel, R. Kaiser // Hessisches Arzteblatt. - 2003. - № 9. - S. 393-394.

7. Kaiser R. Arbeitsbedingungen und Arbeitszufriedenheit von Arzten im Krankenhaus / R. Kaiser // Deutscher ArzteVerlag. - 2002. - S. 45-48.

8. Kohler S. Junge Arzte - Ausstieg aus der Patientenversorgung? / S. Kohler, R. Kaiser // Hessisches Arzteblatt. - 2003. - №9. -S. 462-464.

9. Maulen B. Forderung der Arztegesundheit: Es besteht Nachholbedarf/ B. Maulen // Dtsch. Arztebl. - 2002. - № 99. S. 34-39.

10. Schober B. Young physicians' competences from different points of view / B. Schober, C. Spiel, R. Reimann // Med Teach. - 2004. - № 26(5). - P. 451-457.

11. Trappl R. Wissenschaft und Medizin / R. Trappl. Facultas, 2005. $-192 \mathrm{~s}$. 